\title{
Establishment of three novel cell lines derived from African American patients with colorectal carcinoma: A unique tool for assessing racial health disparity
}

\author{
JENNY PAREDES ${ }^{1 *}$, PING JI ${ }^{2,3 *}$, JOSEPH F. LACOMB ${ }^{3 *}$, KENNETH R. SHROYER ${ }^{4}$, \\ LAURA A. MARTELLO ${ }^{1}$ and JENNIE L. WILLIAMS ${ }^{2,3}$ \\ ${ }^{1}$ Department of Medicine, Division of Gastroenterology \& Hepatology, SUNY Downstate Medical Center, \\ Brooklyn, NY 11203; Departments of ${ }^{2}$ Family, Population and Preventive Medicine, \\ ${ }^{3}$ Medicine and ${ }^{4}$ Pathology, Stony Brook University, Stony Brook, NY 11794, USA
}

Received September 22,2017; Accepted June 26, 2018

DOI: $10.3892 /$ ijo.2018.4510

\begin{abstract}
The incidence and mortality rates of colorectal carcinoma (CRC) are higher among African Americans (AAs) compared with Caucasian Americans (CAs). To assess the molecular properties associated with racial health disparity, three cell lines derived from colorectal tumors of three AA subjects were established. Cellular and molecular characterization of the cell lines designated CHTN06, SB501 and SB521 was performed using standard technologies, including immunofluorescence, electron microscopy, karyotyping, reverse transcription-polymerase chain reaction, ELISA and immunoblot analysis. The histology and morphology of CHTN06 xenografts were examined by hematoxylin and eosin staining. A total of three AA CRC cell lines derived from primary tumors were established and characterized. These cell lines were successfully cultured without immortalization and were found to be tumorigenic as mouse xenografts. In the present study, immunoblotting and immunofluorescence confirmed the expression of proteins known to be dysregulated in CRC, such as p53, DNA mismatch repair proteins and villin-1. Oncogenic miRNAs (i.e., miR-17, miR-21, miR-182, miR-210 and miR-222) were overexpressed in the AA CRC lines compared with the CA CRC lines (HT-29, HCT116
\end{abstract}

Correspondence to: Dr Jennie L. Williams, Department of Family, Population and Preventive Medicine, Stony Brook University, 100 Nicholls Road, HSC, T17-080, Stony Brook, NY 11794, USA

E-mail: Jennie.Williams@stonybrookmedicine.edu

*Contributed equally

Abbreviations: CRC, colorectal cancer; AA, African American; CA, Caucasian American; ATCC, American Type Culture Collection; CHTN, Cooperative Human Tissue Network; SBUMC, Stony Brook University Medical Center

Key words: racial health disparity, chemoprevention, colorectal carcinoma, microRNA and SW480). Additionally, the AA CRC cell lines exhibited a differential inflammatory profile compared with HT-29 (CA CRC cell line); specifically noted was IL-8 secretion in response to inflammatory stimuli. In conclusion, three novel cell lines derived from AA CRC tissues were generated. These cell lines were characterized as epithelial in nature and exhibited differential expression of several miRNAs and inflammatory responses compared with commercially available cell lines of CA origin. The CRC cell lines CHTN06, SB501 and SB521 represent novel tools that may be used to provide diverse in vitro and in vivo models for studying CRC and racial health disparity.

\section{Introduction}

The frequency and mortality of colorectal cancer (CRC) in the United States is markedly higher among African Americans (AAs) compared with all other ethnic/racial groups (1). While socioeconomic factors, such as poor diet and absence of preventive medical care, may be associated with increased incidence and reduced early detection and treatment, it has been reported that AAs with high-grade CRCs had a mortality rate three times higher compared with that in Caucasian Americans (CAs) after controlling for such factors (2). A number of studies have reported a 30-50\% higher rate of CRC mortality in AAs after diagnosis compared with CAs. Additionally, these studies concluded that racial health disparity continues to expand in spite of increased CRC screening (3-8). An important factor necessitating early detection is the observation that AAs develop and are diagnosed with CRC at a younger age compared with CAs (9). Furthermore, it has been demonstrated that variations exist in AA patients, specifically in mutations of the mismatch repair genes hMLH1 and hMSH2 (10) and the $p 53$ tumor suppressor gene (11). Altogether, we may theorize that molecular differences are the impacting influence for racial disparity in CRC frequency and mortality.

A number of studies defining epigenetic and genetic differences, as well as chemotherapeutic response in CRC, have been performed using cell lines derived from CA patients. The 
general lack of AA and Hispanic American (HA) CRC cell lines necessitates the establishment and characterization of cell lines that span diverse populations for use in functional in vitro and in vivo analyses to address racial health disparity. To date, CRC cell lines of AA background are not available, commercially or otherwise, for academic research purposes. This fact was confirmed following an exhaustive literature search by our laboratory, as well as a thorough investigation conducted by the American Type Culture Collection (ATCC). The protective effects of non-steroidal anti-inflammatory drugs (NSAIDs) in CRC $(12,13)$ and the role of the proinflammatory cytokines interleukin (IL)-8 and tumor necrosis factor (TNF)- $\alpha$ in cancer progression $(14,15)$ have been extensively investigated, albeit using predominately CA CRC cell lines. Concurrently, findings that correlated the effect of daily intake of NSAIDs (i.e., aspirin) with genetic polymorphisms in AA $(16,17)$ prompted the need for evaluation of inflammatory profiles in AA CRC tumor cells with the use of CA CRC cells as comparative control.

In the present study, we established, characterized and validated three cancer cell lines derived from AA patients with CRC. Tissue for the cell line designated CHTN06 was obtained from the Cooperative Human Tissue Network (CHTN). Tissues for the cell lines designated SB501 and SB521 were acquired from Stony Brook University Medical Center (SBUMC). We herein describe the morphological and genetic properties of all three cell lines using an array of analyses, including but not limited to microscopy, reverse transcription-quantitative polymerase chain reaction (RT-qPCR) and protein expression assays. These results were directly compared to those of the HT-29, HCT116 and SW480 CRC cell lines, derived from CA patients and obtained from ATCC. Overall, the CHTN06, SB501 and SB521 cell lines exhibited fundamental characteristics of CRC common to the commercially available cell lines, with several biologically dissimilar features. The generation and characterization of these cell lines is expected to provide model systems for studies addressing racial health disparity, chemoprevention and chemo-responsiveness in CRC.

\section{Materials and methods}

Ethics statement. The present study was approved by the Stony Brook University Institutional Review Board (approval no. 93677). Patient CRC samples and metadata obtained from CHTN and SBUMC were completely de-identified, assigned independent patient codes prior to release to the researchers, and qualified for a waiver of consent per 45CFR46.116.d.

Tumor cell isolation and establishment in primary culture. In a sterile tissue culture environment, excess fat and normal tissue were removed and the remaining tumor was washed in 1X Hank's Balanced Salt Solution (Sigma-Aldrich, Merck KGaA, Darmstadt, Germany). Tumors were minced into 1-3-mm3 sections and incubated in dissociation medium (Sigma-Aldrich; Merck KGaA) containing Dulbecco's modified Eagle's medium (DMEM)/F12 (1:1; Corning Cellgro, Manassas, VA, USA) growth medium supplemented with $1 \mathrm{mg} / \mathrm{ml}$ collagenase, type IV (Sigma-Aldrich; Merck KGaA), 10\% (v/v) fetal bovine serum (FBS; Atlanta Biologicals, Lawrenceville, GA, USA), $100 \mathrm{U} / \mathrm{ml}$ penicillin,
$100 \mu \mathrm{g} / \mathrm{ml}$ streptomycin (both from Corning Cellgro), $2.5 \mu \mathrm{g} / \mathrm{ml}$ amphotericin B (Life Technologies; Thermo Fisher Scientific, Auckland, New Zealand), $100 \mu \mathrm{g} / \mathrm{ml}$ gentamycin, $10 \mathrm{ng} / \mathrm{ml}$ insulin (both from Sigma-Aldrich; Merck KGaA) and $10 \mu \mathrm{g} / \mathrm{ml}$ ciprofloxacin (GenHunter, Nashville, TN, USA). Dissociated tissue was filtered through a $100-\mu \mathrm{m}$ cell strainer (BD Biosciences, Bedford, MA, USA) to remove undigested tissue fragments and washed in phosphate-buffered saline (PBS; Corning Cellgro). Cells were cultured in primary growth medium in a humidified incubator at $37^{\circ} \mathrm{C}$ in $5.0 \% \mathrm{CO}_{2}$. Primary growth medium consisted of DMEM (Corning Cellgro) supplemented with $10 \% \mathrm{FBS}, 100 \mathrm{U} / \mathrm{ml}$ penicillin, $100 \mathrm{U} / \mathrm{ml}$ streptomycin, $15 \mu \mathrm{g} / \mathrm{ml}$ ciprofloxacin, $2.5 \mu \mathrm{g} / \mathrm{ml}$ amphotericin B, $50 \mu \mathrm{g} / \mathrm{ml}$ gentamycin, $0.25 \mathrm{ng} / \mathrm{ml}$ epidermal growth factor, $1 \%$ insulin, $5 \mathrm{mg} / \mathrm{ml}$ transferrin and $20 \mu \mathrm{g} / \mathrm{ml}$ selenium (all from Sigma-Aldrich; Merck KGaA).

The CRC cell lines HT-29, HCT116 and SW480 were commercially obtained from ATCC (Manassas, VA, USA). Each cell line was maintained in its respective culture media as defined by ATCC: McCoy's 5A, F-12K, or DMEM (Corning Cellgro) supplemented with $10 \% \mathrm{FBS}, 100 \mathrm{U} / \mathrm{ml}$ penicillin and $100 \mu \mathrm{g} / \mathrm{ml}$ streptomycin. Cells were cultured in a humidified incubator at $37^{\circ} \mathrm{C}$ in $5.0 \% \mathrm{CO}_{2}$.

Transmission electron microscopy (TEM). CHTN06, SB501 and SB521 samples used for TEM were processed using standard techniques. Briefly, cells were grown on gridded ACLAR (Electron Microscopy Sciences, Fort Washington, PA, USA), a copolymer film commonly used in electron microscopy, and fixed in $2.5 \%$ electron microscopy-grade glutaraldehyde in 0.1 M PBS (pH 7.4). The samples were then placed in $1.0 \%$ osmium tetroxide in $0.1 \mathrm{M}$ PBS ( $\mathrm{pH} 7.4)$, dehydrated in a gradient series of ethyl alcohol and embedded in Durcupan resin (Sigma-Aldrich; Merck KGaA). Ultrathin sections $(80 \mathrm{~nm})$ were cut with a Leica EM UC7 ultramicrotome (Leica Microsystems Inc., Buffalo Grove, IL, USA) and placed on Formvar-coated single-slot copper grids. The sections were then counterstained with uranyl acetate and lead citrate. The samples were imaged using a FEI Tecnai12 BioTwinG $^{2}$ transmission electron microscope (Field Emission Inc., Hillsboro, OR, USA) and digital images were acquired with an AMT XR-60 CCD Digital Camera system (Advanced Microscopy Techniques, Woburn, MA, USA).

Karyotyping. Mitotic cells were arrested in metaphase by treatment with $0.5 \mu \mathrm{g} / \mathrm{ml}$ demecolcine (Sigma-Aldrich; Merck KGaA) for $3 \mathrm{~h}$ in a humidified incubator at $37^{\circ} \mathrm{C}$ in $5.0 \% \mathrm{CO}_{2}$. Harvested cells were then made turgid by incubating in hypotonic buffer for $45 \mathrm{~min}$ at $37^{\circ} \mathrm{C}$ and subsequently fixed in Carnoy's fixative (3:1, methanol:glacial acetic acid). Cells were spread onto microscopy slides and adhered by drying over a hot plate. Chromosomes were stained with DAPI (Sigma-Aldrich; Merck KGaA) and imaged using a Nikon Eclipse 90i microscope (Instruments, Inc.; Edgewood, NY, USA) at a magnification of $\mathrm{x} 60$.

Cell viability/proliferation assay. Cell viability/proliferation was measuredusing the 3-(4,5-dimethylthiazol-2-yl)-2,5-diphenyltetrazolium bromide (MTT) colorimetric assay according to the manufacturer's protocol (Sigma-Aldrich; Merck KGaA). 
Cells were seeded in 96-well tissue culture-treated plates at a density of $1 \times 10^{4}$ cells/well and cultured overnight at $37^{\circ} \mathrm{C}$ in $5.0 \% \mathrm{CO}_{2}$. MTT reagent I was added to each well and incubated at $37^{\circ} \mathrm{C}$ in $5.0 \% \mathrm{CO}_{2}$ for $4 \mathrm{~h}$, after which time the MTT reagent II solubilization solution was added. Samples treated with reagents were incubated overnight at $37^{\circ} \mathrm{C}$ in $5.0 \% \mathrm{CO}_{2}$. Optical density, defining cell viability/proliferation, was determined using a SpectraMax i3 spectrophotometer plate reader (Molecular Devices, Sunnyvale, CA, USA) at $590 \mathrm{~nm}$. Results obtained from the MTT proliferation assay were validated using the trypan blue (Corning Cellgro) exclusion method.

Cell invasion assay. Invasion assays were conducted in triplicate using BioCoat ${ }^{\mathrm{TM}}$ Matrigel $^{\odot}$ invasion chambers (BD Biosciences) with pre-coated $8.0-\mu \mathrm{M}$ mesh membrane inserts. FBS (10\%) in McCoy's 5A medium was used as the chemoattractant in the outer chamber of the well for the HT-29 and HCT116 cell lines, whereas DMEM supplemented with 10\% FBS was used for the three AA CRC cell lines. For all cell lines, $5 \times 10^{4}$ cells/ $\mathrm{ml}$ were suspended in their respective medium with $0.5 \% \mathrm{FBS}$, seeded into the inner chamber of the well and incubated at $37^{\circ} \mathrm{C}$ in $5.0 \% \mathrm{CO}_{2}$ for $24 \mathrm{~h}$. After incubation, non-invading cells were aspirated from the chamber and the Matrige ${ }^{\odot}{ }^{\odot}$ layer was removed from the mesh membranes. Invading cells entrapped in the membrane were fixed with $100 \%$ methanol and stained with $0.5 \%$ crystal violet solution (Sigma-Aldrich; Merck KGaA). For each membrane, 8 fields of view at $\times 20$ under a phase-contrast microscope were quantified and averaged.

Histological and morphological evaluation of tumors. All animals were treated strictly in accordance with the National Institutes of Health guidelines for the care and use of laboratory animals, and the protocols used were approved by the Institutional Animal Care and Use Committee at the State University of New York at Stony Brook (IACUC; Animal Welfare Assurance no. A3011-01). Female NOD SCID mice, aged 5-6 weeks (Harlan Laboratories, Indianapolis, IN, USA), were subcutaneously injected with cells in $100 \mu \mathrm{l}$ PBS into each flank (left and right). One mouse $(\sim 25 \mathrm{gr})$ per cell line was used to generate the original xenografts. One mouse was used for generation of each subsequent passage (up to F4). All animals were maintained under controlled conditions $\left(21^{\circ} \mathrm{C}\right.$ and $50 \%$ relative humidity in a 12 -h light/dark cycle), fed ad libitum with free access to water and examined at least twice daily. Tumors were generated either singularly in one flank, or bilaterally in the left and right flanks. In all cases, the maximal allowable tumor size of each individual tumor was $1.5 \mathrm{~cm}$ with a body condition score of 3 (wellconditioned). The mice were monitored daily. A protocol was in place to humanely euthanized tumor-bearing mice upon evidence of distress, as defined by IACUC policy. Tumor volume was calculated using the equation: Volume $\left(\mathrm{mm}^{3}\right)$ $=[$ length $\mathrm{x}$ width $\mathrm{x}$ (length + width/2) $\mathrm{x} 0.56](18)$. At the end of the studies, xenografts were harvested, cross-linked in $10 \%$ formalin fixative, and embedded into paraffin blocks using a standard protocol for specimen dehydration and paraffin embedding (19). Embedded tissues were then sliced into $5.0-\mu \mathrm{m}$ sections. The sections were fixed onto slides and hematoxylin and eosin (H\&E) staining was performed as previously described (20). Cellular morphology and histology were examined via photomicroscopy by a board-certified pathologist.

Immunohistochemistry (IHC). IHC was performed as previously described (21). Sections $(5.0-\mu \mathrm{m})$ of formalin-fixed paraffin-embedded xenograft tumors were deparaffinized and probed with primary antibody against carcinoembryonic antigen (CEA; Abcam, Cambridge, MA, USA) diluted 1:500 or IgG isotype control overnight at $4^{\circ} \mathrm{C}$. Biotinylated secondary antibody and the streptavidin biotin complex (Invitrogen; Thermo Fisher Scientific, Carlsbad, CA, USA) were applied and counterstaining for nuclei was performed using hematoxylin (Sigma-Aldrich; Merck KGaA).

Immunofluorescence microscopy. Cells were washed with PBS and cross-linked with ice-cold 100\% methanol (PharmcoAAPER, Brookfield, CT, USA). Cells were permeabilized with $0.1 \%$ Triton X-100/PBS. Non-specific binding of antibodies was blocked by incubating in $2.0 \%$ bovine serum albumin/PBS. Cells were incubated with p53 (Santa Cruz Biotechnology, Dallas, TX, USA), p50, p65 (both from Upstate Cell Signaling, Lake Placid, NY, USA), villin-1, MSH2, E-Cadherin (all from Cell Signaling Technology, Inc., Danvers, MA, USA), CEA, or IgG control antibody (Santa Cruz Biotechnology) overnight at $4^{\circ} \mathrm{C}$. Subsequently, cells were incubated with Alexa Fluor ${ }^{\circledR} 488$ anti-rabbit secondary antibody (1:2,000; Invitrogen; Thermo Fisher Scientific) at room temperature for $1 \mathrm{~h}$, and the nuclei were stained using DAPI. A Nikon Eclipse 90i Fluorescence microscope was used for detection of protein expression at a magnification of $\mathrm{x} 20$. A pathologist who was blinded to sample identity qualitatively evaluated the slides. The staining of cells was scored as positive or negative and cytoplasmic and/or nuclear.

Immunoblot analysis. Cells were washed with ice-cold PBS and lysed on ice with RIPA lysis buffer [50 mM Tris- $\mathrm{HCl}$ ( $\mathrm{pH} 7.4)$, $150 \mathrm{mM} \mathrm{NaCl}, 1 \mathrm{mM}$ Na2EDTA, 1\% NP-40, 0.25\% sodium deoxycholate] (Sigma-Aldrich; Merck KGaA) supplemented with $1 \mathrm{mM}$ phenylmethylsulfonyl fluoride (PMSF; SigmaAldrich; Merck KGaA) and Protease Inhibitor Cocktail 2 (Sigma-Aldrich; Merck KGaA). Protein quantification was achieved using the Quick Start ${ }^{\mathrm{TM}}$ Bradford protein assay (BioRad Laboratories, Inc., Hercules, CA, USA). Isolated proteins (20 $\mu \mathrm{l} /$ well) were fractionated by sodium dodecyl sulfatepolyacrylamide gel electrophoresis (7.5\% SDS-PAGE) and transferred onto a polyvinylidene difluoride (PVDF) membrane (Bio-Rad Laboratories, Inc.). Probing with antibodies for CEA (Thermo Fisher Scientific; cat. no. PA5-16665), $\beta$-catenin (BD Biosciences; cat. no. 610153), and antibodies purchased from Cell Signaling Technology, which included p53 (cat. no. MA5-12453), p50 (cat. no. 51-3500), p65 (cat. no. 51-0500), E-cadherin (cat. no. PA5-16766 ), villin-1 (cat. no. PA5-22072), MSH2 (cat. no. PA5-29160), MSH6 (cat. no. PA5-29348), MLH1 (cat. no. PA5-78062), and ezrin (cat. no. PA1-090) was performed overnight at $4^{\circ} \mathrm{C}$. $\beta$-tubulin (cat. no. 05-661; Millipore, Temecula, CA, USA) was used as a loading control. All primary antibodies were incubated overnight at $4^{\circ} \mathrm{C}$. Subsequently, blots were incubated with secondary antibodies (Santa Cruz Biotechnology), m-IgGK BP-HRP (cat. no. sc-516102) or mouse anti-rabbit IgG-HRP (cat. no. sc-2357), 
for $1 \mathrm{~h}$ at room temperature. Protein expression was analyzed using a luminol-based enhanced chemiluminescence reaction kit (Amersham Biosciences; GE Healthcare, Little Chalfont, UK). Quantification of staining levels was determined by densitometry of western blot analyses normalized to $\beta$-tubulin.

Total cellular RNA extraction. Total cellular RNA, including microRNA (miRNA), was isolated from cell lines by using the Illustra TriplePrep Kit (Amersham Biosciences; GEHealthcare) according to the manufacturer's protocol. Quantification of RNA was determined using a NanoDrop 2000C spectrophotometer (Thermo Fisher Scientific, Rockford, IL, USA).

$R T-q P C R$. For all samples, cDNA was synthesized from $20 \mathrm{ng}$ of total cellular RNA using the Universal cDNA Synthesis Kit (Exiqon, Woburn, MA, USA). After reverse transcription, quantification of candidate miRNAs (miR-182, miR-204, miR-210 and miR-128) was determined using commercially available specific miRNA LNA PCR primers (Exiqon). qPCR was conducted using Universal RT SYBR Green master mix (Exiqon) in a Realplex Real-time PCR machine (Eppendorf, Hauppauge, NY, USA). RT-PCR was performed under the following cycling conditions: $95^{\circ} \mathrm{C}$ for $10 \mathrm{~min}$, and 45 cycles of $95^{\circ} \mathrm{C}$ for $10 \mathrm{sec}$ and $60^{\circ} \mathrm{C}$ for $1 \mathrm{~min}$. All RT-qPCRs were performed in triplicate. Transcript normalization of samples was obtained using SNORD44 as a control gene reference.

ELISA. A total of $2 \times 10^{5}$ cells of each cell line (SB-501, CHTN-06, SB-521 and HT-29) were seeded separately on 12 -well plates and incubated for $48 \mathrm{~h}$ with DMEM cell culture media supplemented as previously described. Next, the media were removed and replaced with non-supplemented DMEM. TNF- $\alpha$ (30 ng) was added to the cells and stimulation was allowed to proceed for $6 \mathrm{~h}$. Control wells were not treated with TNF- $\alpha$. Each cell line was treated in triplicates with 3 replicates performed. Supernatants were collected and kept at $-20^{\circ} \mathrm{C}$ for later analysis using ELISA. IL- 8 secretion was detected by the use of the Human IL-8 kit (EHL-IL8; RayBiotech Inc., Norcross, GA, USA) according to the manufacturer's instructions.

Statistical analysis. One-way analysis of variance was used to determine whether there were any statistically significant differences between the methods of treatment for the various groups of each cell line. P-values were considered significant at values of $<5 \%$ uncertainty or 0.05 . Three independent experiments were analyzed for each treatment group.

\section{Results}

Origin and morphology of AA CRC cell lines. The CRC cell lines CHTN06, SB501 and SB521 were derived from a liver metastasis from a 69-year-old AA woman, a stage $3 \mathrm{~b}$ cecum adenocarcinoma from a 64-year-old AA woman, and a stage 3c splenic flexure adenocarcinoma from a 53-year-old AA man, respectively. Once established in vitro, CHTN06 and SB501 cells were viable as adherent cells when cultured on a standard cell culture-treated surface without a supplemental coating of attachment factors (i.e., fibronectin or fibrinogen). Over $90 \%$ of the cells in culture were epithelial-like. Both cell lines exhibited polymorphic characteristics, with a spindle or polygonal morphology, and proliferated as tightly bound colonies. Conversely, SB521 cells were viable as a heterogeneous population of adherent and suspension cells when grown under the same conditions. This line does not grow in dense colonies and is heterogeneous in terms of cellular morphology.

IHC staining for CEA, a CRC epithelial marker, was conducted to validate the lineage of all three cell lines. CHTN06, SB501 and SB521 were all positive for the CEA protein (Fig. 1A). Therefore, these novel in vitro models were validated as epithelial CRC cell lines. Via TEM analysis, all three cell lines were shown to be mononucleated with a dense nucleolus (Fig. 1B, arrow). At higher magnification, tight junctions were visible between adjacent cells (data not shown). All other organelles, including mitochondria, Golgi and endoplasmic reticulum, had normal physiology and were otherwise unremarkable.

Cytogenetic analysis. Karyotyping analysis was performed at a subculture passage of 4 for all cell lines (Fig. 1C). CHTN06 cells were near-diploid, with a modal number of 45 chromosomes; SB501 cells were hypotriploid, with a modal of 65 chromosomes; and SB521 cells were hypodiploid, with a modal number of 43 chromosomes. Karyotyping also determined a modal number of 45 chromosomes for HCT116 cells, whereas HT-29 cells were hypertriploid, with a modal number of 71 chromosomes (data not shown), which was confirmed by ATCC. Karyotyping for SW480 cells was not performed; however, this cell line has been reported to be hypotriploid by ATCC (https://www.atcc.org/en/Products/All/CCL-228. aspx\#characteristics).

Genetic profiling and stability of AA CRC cell lines. To confirm conservation of the genetic profile of the original patient sample to that of successive passages, short tandem repeat (STR) DNA profiling of multiple passages was performed (Genetica DNA Laboratories, Burlington, NC, USA). The STR DNA profiling of CHTN06 (100\% match) and SB501 (92.3\% match) confirmed that both cell lines were authentic from the original patient tissue, with no or minimal genetic drifting. Furthermore, each line was a homogeneous cell population, as 1-2 alleles were identified for each locus analyzed.

Genetic drift was observed in the SB521 line, with a $68.1 \%$ match of cell passages from the original patient specimen. To determine the cause of genetic drifting, microsatellite instability (MSI) testing was performed (Genetica DNALaboratories). This cell line was found to display high-level MSI (MSI-H). Immunoblot analysis of select mismatch repair (MMR) proteins revealed that MLH1 expression was not detectable, MSH2 expression was decreased (2.2-fold) and MSH6 expression was mildly increased (1.3-fold) compared with HT-29.

A search using the respective STR DNA profile of each AA $C R C$ cell line revealed that these profiles were not found in any known cell repositories. Thus, the CHTN06, SB501 and SB521 cell lines are novel and unique in vitro/in vivo tools for studying biological factors involved in CRC progression and those attributing to racial health disparity. Furthermore, SB521 may be employed to assess the general biology of CRC in AAs with MSI-H genetic profile. 


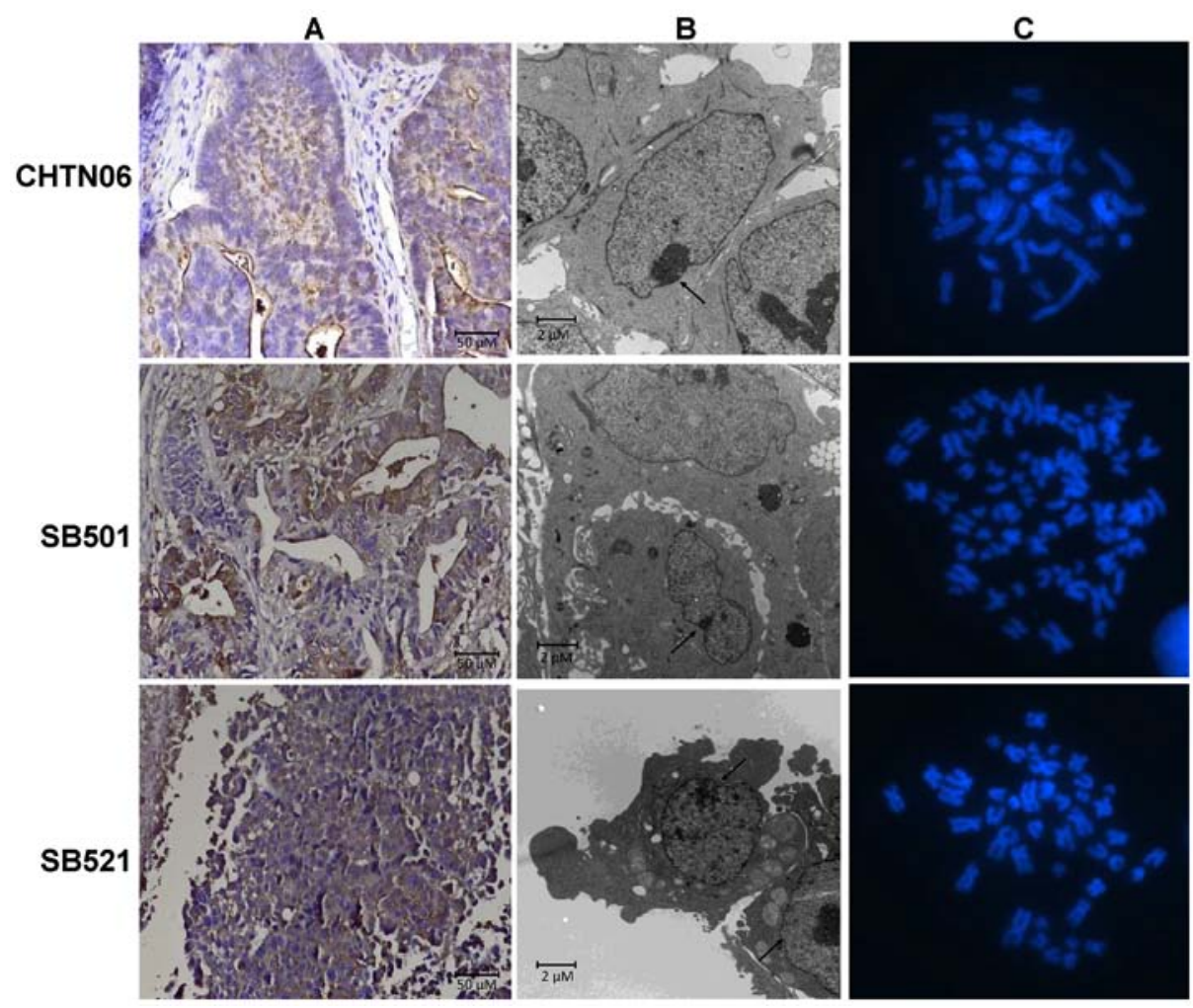

Figure 1. Origin and morphology of African American colorectal carcinoma cell lines. (A) Immunohistochemical staining for carcinoembryonic antigen in the three cell lines confirmed that CHTN06, SB501 and SB521 are gastrointestinal tract-derived epithelial cell lines (magnification, x20). (B) Transmission electron microscopy imaging in the three cell lines depicted mononucleated cells, with tight junctions between adjacent cells confirming the epithelial nature of CHTN06, SB501 and SB521 (magnification, x14,900). Arrow in each panel indicates nucleolus. (C) Representative karyotype of the three cell lines; CHTN06 with a modal number of 45, SB501 with a modal number of 65, and SB521 with a modal number of 43 . The modal numbers for HCT 116 and HT-29 were in agreement with those listed by American Tissue Type Collection (data not shown).

Cellular proliferation and invasion properties. All three cell lines were viable and readily proliferated in growth medium supplemented as described in Materials and methods. The logarithmic growth phase occurred between 24 and $96 \mathrm{~h}$. The proliferation rate (mean doubling time during log growth) was $29.4 \pm 2.3 \mathrm{~h}$ for CHTN06, 34.0 $\pm 2.2 \mathrm{~h}$ for SB501, and $19.5 \pm 1.5 \mathrm{~h}$ for SB521, as determined by MTT proliferation assays. The maximal mitotic index (rate of growth) occurred at $\sim 72-96 \mathrm{~h}$ (data not shown) for all three cell lines. As reported by ATCC, the established proliferation rate is $21 \mathrm{~h}$ for HCT $116,23 \mathrm{~h}$ for HT-29 and $38 \mathrm{~h}$ for SW480.

An invasion assay was conducted to evaluate the invasive properties of the three AA CRC cell lines compared with the established CA CRC cell lines. After a 24-h incubation, SB501 cells exhibited an invasion rate of $24.3 \pm 3.0$ cells/field of view (FOV). This rate was significantly lower compared with that of the HCT116 cell line $(45.3 \pm 8.1$ cells/FOV). However, the rate was not different compared with the HT-29 cell line $(26.8 \pm 8.7$ cells/FOV). The invasion rate of CHTN06 $(45.9 \pm 13.0 \mathrm{cells} / \mathrm{FOV})$ and SB521 $(34.0 \pm 5.0 \mathrm{cells} / \mathrm{FOV})$ were not considered to be significantly different from the two CA CRC lines. Control wells lacking the FBS chemoattractant produced significantly fewer invasive cells for all three cell lines (Fig. 2A).

The in vivo tumorigenic properties of the three AA CRC cell lines were studied using a mouse xenograft model. Cells suspended in PBS were subcutaneously injected bilaterally into SCID mice. The xenograft tumors of all three cell lines were readily established and grew to a mean volume of $1,600 \mathrm{~mm}^{3}$ over 21 days (Fig. 2B). Histology revealed the grafted tumors to be highly differentiated, displaying glands with crowded, elongated and dysplastic nuclei, in a background of necrosis with acute inflammation, highly consistent with well-differentiated colorectal adenocarcinoma (Fig. 2C-E). Cells dissociated and cultured from harvested xenograft tumors retained the same properties as the original cell line.

$A A C R C$ cell lines express hallmark CRC properties. To further characterize the three AA CRC cell lines, proteins associated with $\mathrm{CRC}$ tumorigenesis and progression, i.e., $\beta$-catenin, p53, NF- $\mathrm{KB}$ (p50 and p65), villin-1, MSH2, MSH6, MLH1, E-cadherin, ezrin and CEA, were assessed by western blotting and immunofluorescence analysis. The protein expression of each AA CRC line was directly compared to that of HT-29, whereas CHTN06 was additionally evaluated against HCT116 and SW480 (data not shown). No significant changes in $\beta$-catenin expression were observed in the CHTN06, SB501 or SB521 cell lines compared with the HT-29 cell line (Fig. 3). Conversely, a marginal 1.3 -fold increase or decrease in $\beta$-catenin expression was observed in CHTN06 relative to the HCT116 and SW480 cell lines, respectively (data not shown).

p53 expression in CHTN06 and SB521 cells was downregulated to that observed in HT-29 cells, whereas p53 expression in SB501 cells was comparable (Fig. 3). The heterodimeric subunits of NF- $\mathrm{KB}$ (p50 and p65), both of which are commonly overexpressed in CRC (22), were consistent in expression 
A

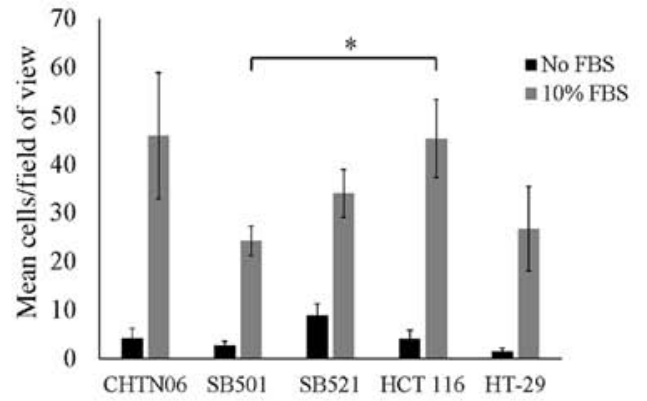

B

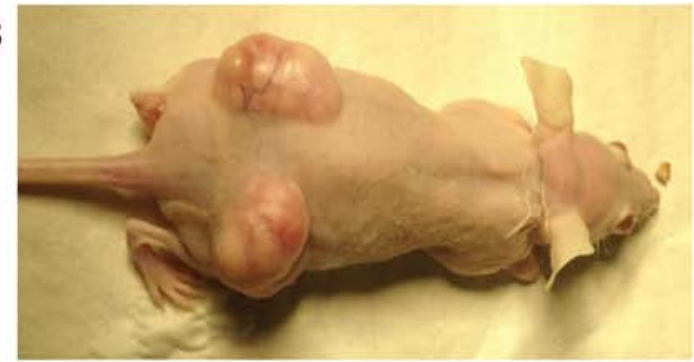

$\mathrm{C}$

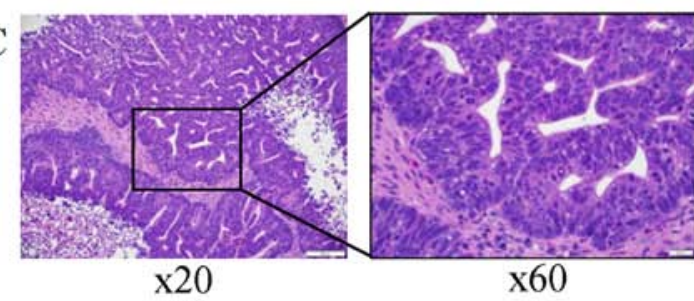

$\mathrm{D}$

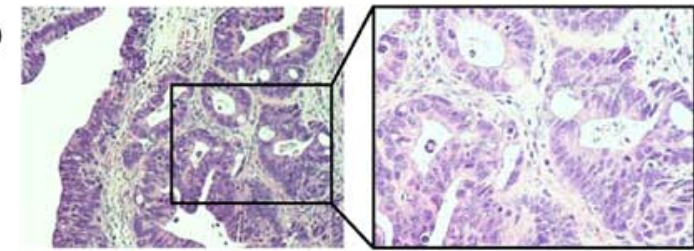

E

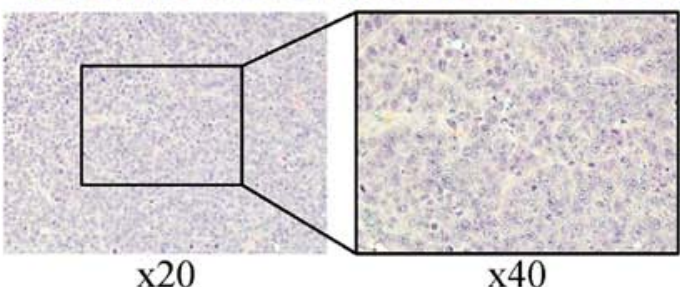

Figure 2. Invasion and in vivo growth properties of the African American (AA) colorectal carcinoma (CRC) cell lines. (A) The three AA CRC cell lines displayed in vitro invasion capacity similar to that of HCT116 and HT-29 cells. (B) In vivo xenograft tumor in a SCID mouse 4 weeks post-graft demonstrates the tumorigenic nature of CHTN06. In all cases, the maximal allowable tumor size of each individual tumor was $1.5 \mathrm{~cm}$, with a body condition score of 3. Hematoxylin and eosin staining of (C) CHTN06, (D) SB501 and (E) SB521 xenografts show representative morphology of the tumor featuring a pseudo-glandular pattern composed of elongated columnar cells with crowded, hyperchromatic nuclei in a background of necrosis (magnification: Left panel, x20 and right panel, x60). FBS, fetal bovine serum.

levels for all AA cell lines compared with HT-29 (Fig. 3). The expression levels of p65 were upregulated in CHTN06, SB501 and SB521 cells relative to HT-29 cells (Fig. 3). The expression levels of villin-1, a member of the calcium-regulated actinbinding family and a marker of differentiation in CRC $(23,24)$, was slightly upregulated in CHTN06, SB521 and SB501 cells compared with HT-29 cells (Fig. 3). No villin-1 expression was detected in the HCT116 and SW480 cell lines (data not shown).
A

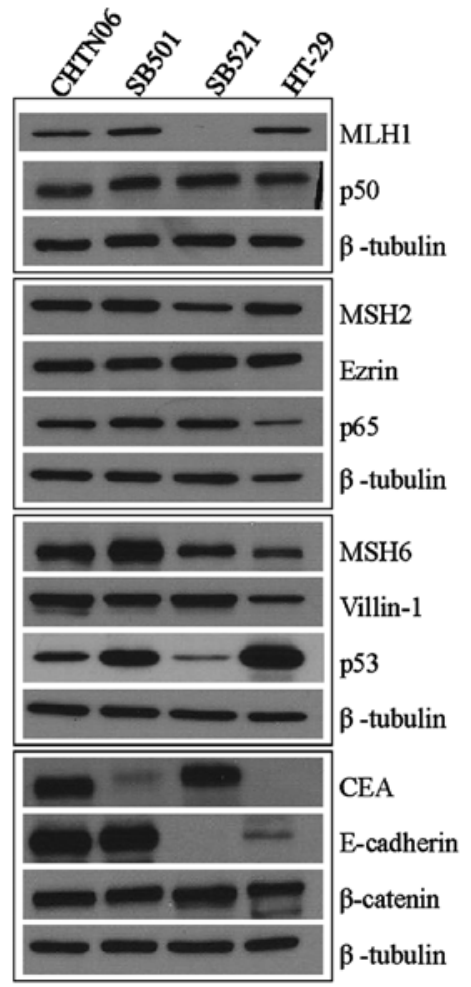

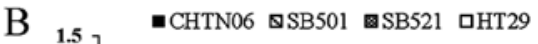

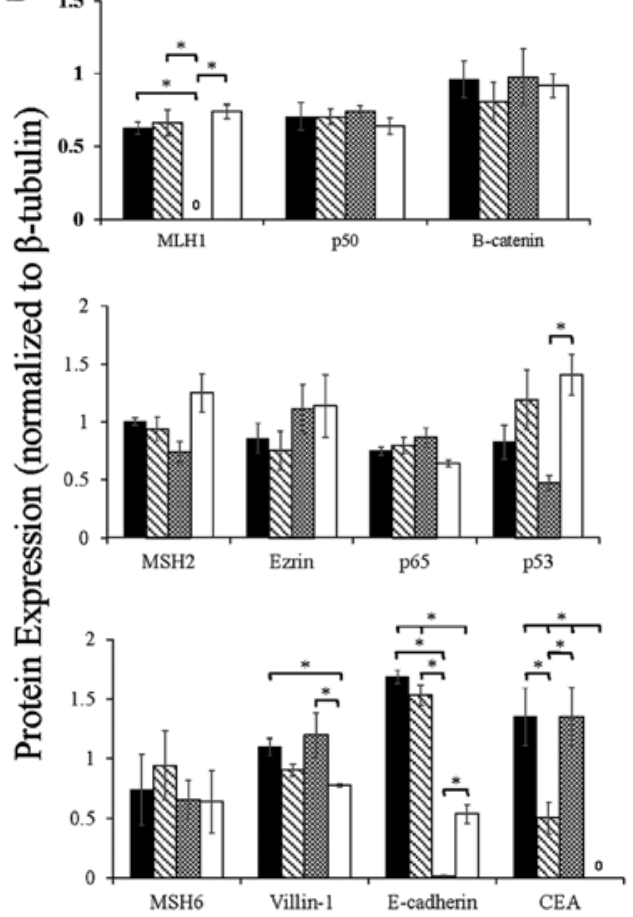

Figure 3. The expression of proteins associated with colorectal carcinoma (CRC) tumorigenesis and metastasis was determined in the novel African American CRC lines by immunoblotting. (A) Qualitative analysis of CHTN06, SB501 and SB521 and HT-29, a Caucasian American CRC cell line, for protein expression of $\beta$-catenin, p53, nuclear factor (NF)- $\mathrm{kB}$ (p50 and p65), villin-1, MSH2, MSH6, MLH1 and ezrin. (B) Semi-quantitative densitometry was performed by normalizing protein expression to the respective $\beta$-tubulin loading control. Data were generated from three independent experiments. CEA, carcinoembryonic antigen.

Selected members of the MMR protein family were analyzed, i.e., MLH1, MSH2 and MSH6. Expression of MLH1 was not detectable in the SB521 cell line, whereas 


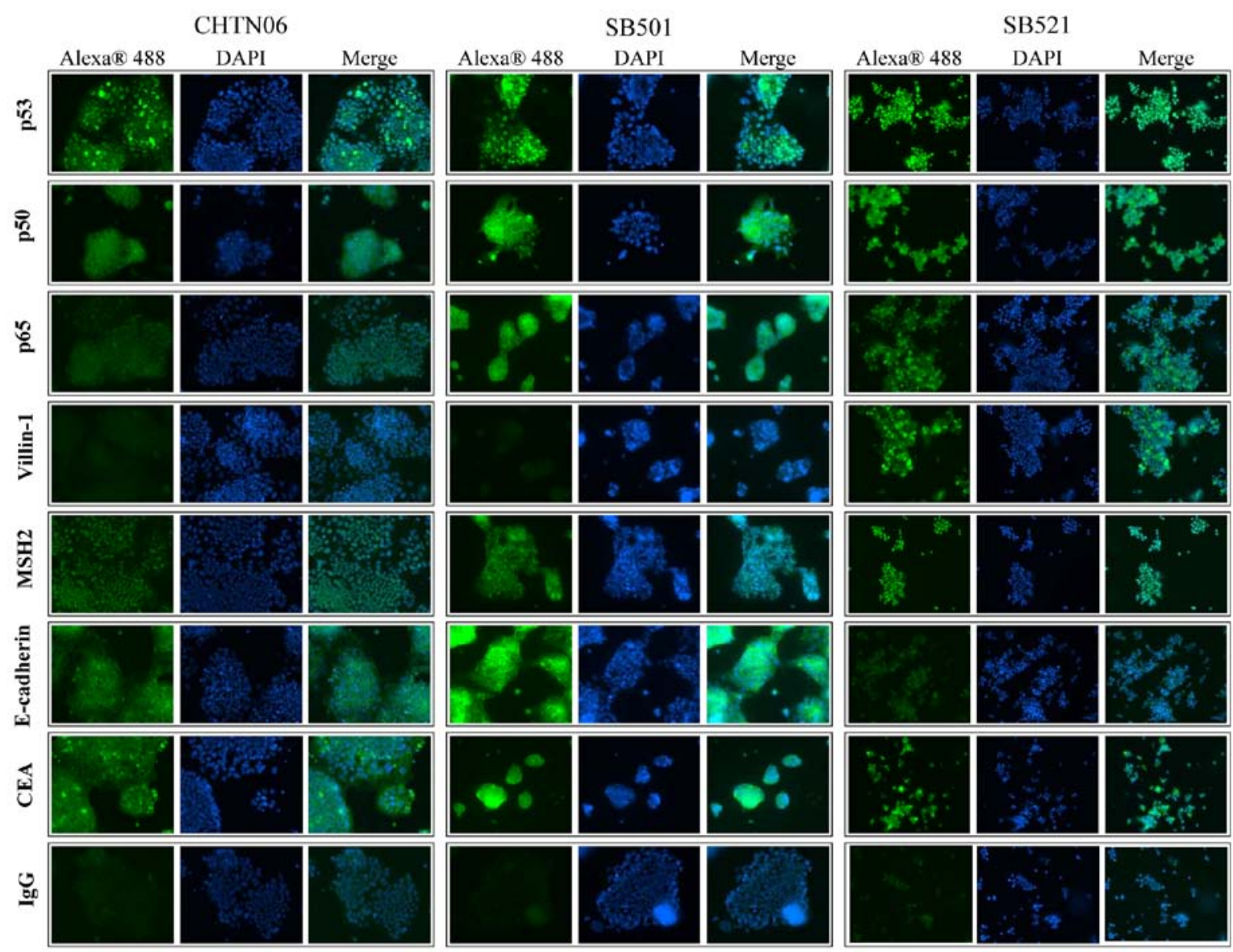

Figure 4. The expression of proteins associated with colorectal carcinoma (CRC) tumorigenesis was further assessed by immunofluorescence. The proteins examined included p53, p50, p65, villin-1, MSH2, E-cadherin and CEA. IgG isotype control was used to differentiate non-specific background staining. Cells were stained with secondary antibody Alexa ${ }^{\circledR} 488$ and DAPI (nuclei). The images were later merged. Magnification, x20. CEA, carcinoembryonic antigen.

its expression in CHTN06 and SB501 cells paralleled that in HT-29 cells (Fig. 3). The expression level of MSH2 was downregulated in CHTN06, SB501 and SB521 cells compared with that in HT-29 cells (Fig. 3). No differences in the expression level of MSH2 were noted in the CHTN06 cell line compared with the HCT116 or SW480 cell lines (data not shown). The expression level of MSH6 was upregulated in the CHTN06, SB501 and SB521 cell lines (Fig. 3) compared with the HT-29 cell line. The expression level of this protein was slightly downregulated in HCT116 cells and slightly upregulated in SW480 cells relative to CHTN06 cells (data not shown).

The expression levels of two proteins involved in cell-to-cell adhesion, namely E-cadherin and ezrin, were also compared among cell lines. The expression level of E-cadherin was markedly upregulated in CHTN06 and SB501 and markedly downregulated in SB521 cells (Fig. 3) relative to HT-29 cells. The expression level of ezrin was mildly upregulated in CHTN06, SB501 and SB521 cells as compared to HT-29 cells (Fig. 3).

Qualitative assessment for selected proteins was performed by immunofluorescence analysis for CHTN06, SB501 and SB521 cells (Fig. 4). In the present study, p53 was found to accumulate in the nucleus of all three AA CRC cell lines. Additionally, expression of the NF- $\kappa \mathrm{B}$ subunits p50 and p65, villin-1, MSH2 and E-cadherin was also observed in all AA cell lines, as was cytosolic expression of CEA. An IgG isotype control was used to differentiate between non-specific background staining.
AA cell lines differentially express specific miRNAs. RT-qPCR was used to analyze the expression levels of several miRNAs in the three novel AA CRC cell lines and the three established CA CRC cell lines: miR-17-5p and $-3 p$, miR-21-5p and $-3 p$, miR128-3p, miR-182-5p, miR-210-3p and miR-222. Differential expression of these miRNAs was observed between AA and CA CRC cell lines. The purported oncomir miR-17-5p was upregulated in CHTN06 compared with SB521 and the three CA CRC cell lines, whereas expression of this miRNA was not detected in the SB501 cell line (Fig. 5A). Additionally, expression of miR17-3p in the SB501 and SB521 cell lines was lower compared with the SW480 and HCT116 CA CRC lines (Fig. 5B). Expression of miR-21-5p and miR-21-3p, frequently upregulated in solid tumors, was downregulated in the three AA CRC lines compared with SW480 and HCT116 (Figs. 5C and 6A). However, the three AA CRC lines expressed higher levels of miR128-3p compared with SW480. Conversely, SB501 exhibited lower expression of this miRNA compared with the HCT116 and HT-29 CA CRC cell lines (Fig. 6B). miR-182-5p was upregulated in CHTN06 compared with two of the CA CRC cell lines (SW480 and HT-29). SB521 exhibited decreased expression compared with HCT116, and no detectable levels were observed in the SB501 cell line (Fig. 6C). As regards miR-210-3p, its expression was increased in the CHTN06 cell line compared with all three CA CRC cell lines, whereas its expression in the SB501 and SB521 cell lines was downregulated compared with the HCT116 cell line. Only a slight 

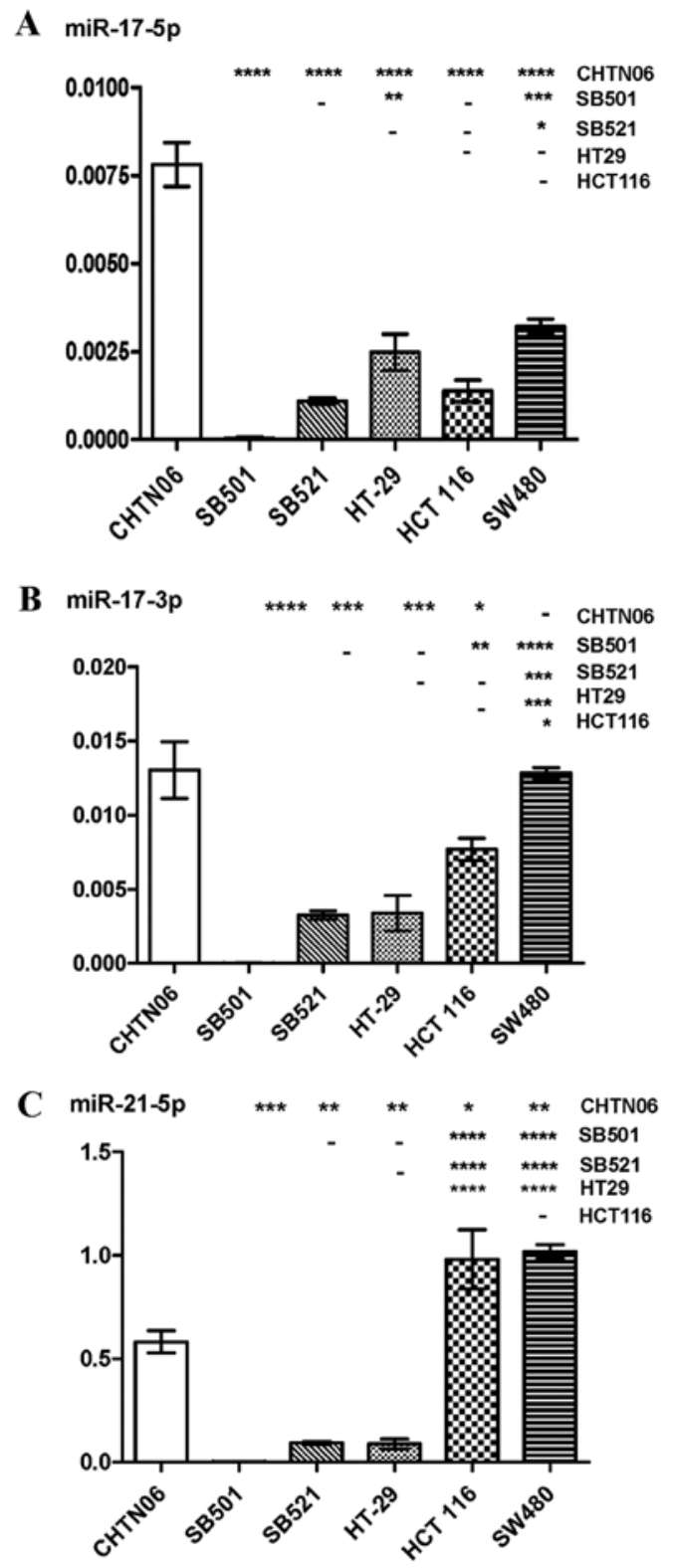

Figure 5. RT-qPCR analysis demonstrated that the expression levels of several miRNAs were dysregulated in African American colorectal carcinoma (CRC) cells compared with other well-characterized human Caucasian American CRC cell lines. (A) miR-17-5p; (B) miR-17-3p; and (C) miR-21-5p Significant differences between cell lines are indicated within the graph -, not significant $(\mathrm{P}>0.05) ;{ }^{*} \mathrm{P} \leq 0.05 ;{ }^{* *} \mathrm{P} \leq 0.01 ;{ }^{* * *} \mathrm{P} \leq 0.001 ;{ }^{* * * *} \mathrm{P} \leq 0.0001$. RT-qPCR, reverse transcription-quantitative polymerase chain reaction.

detectable difference was observed between the SB501 and SB521 AA cell lines compared with the SW480 and HT-29 CA cell lines (Fig. 7A). Decreased miR-222-5p expression was observed in SB501 compared with all three CA CRC cell lines, and in SB521 compared with HCT116 and HT-29 (Fig. 7B). Similarly, SB521 exhibited decreased miR-222-3p expression compared with the three CA CRC cell lines and in SB521 compared with HT-29. The expression of miR-222-5 or $-3 p$ in CHTN06 did not differ significantly compared with any of the CA CRC cell lines (Fig. 7B and C). The P-value for each miRNA is provided in Table $\mathrm{I}$.

AA cell lines differ in inflammatory patterns compared with the CA cell line HT-29. To assess the response to inflammation
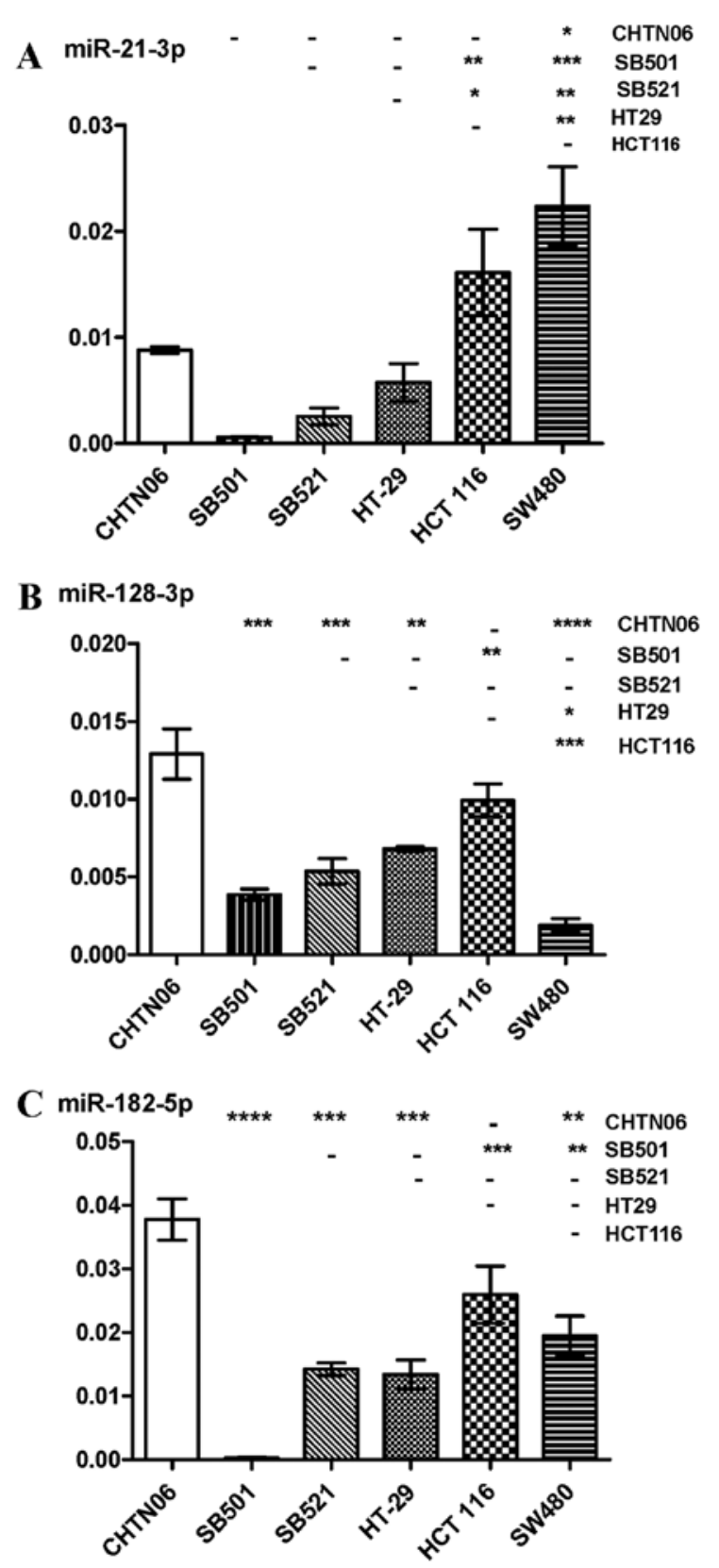

Figure 6. RT-qPCR analysis demonstrated that the expression levels of several miRNAs were dysregulated in African American colorectal carcinoma (CRC) cells compared with other well-characterized human Caucasian American CRC cell lines. (A) miR-21-3p; (B) miR-128-3p; and (C) miR-182-5p. -, not significant $(\mathrm{P}>0.05) ;{ }^{*} \mathrm{P} \leq 0.05 ;{ }^{* *} \mathrm{P} \leq 0.01 ;{ }^{* * *} \mathrm{P} \leq 0.001 ;{ }^{* * * *} \mathrm{P} \leq 0.0001$. RT-qPCR, reverse transcription-quantitative polymerase chain reaction.

in the three AA cell lines (CHTN06, SB501 and SB521), TNF- $\alpha$ was used to induce an inflammatory state and the subsequent secretion of IL-8 was quantified by ELISA (Fig. 8). The AA cell lines, as well as the CA cell line HT-29, demonstrated an increase in the production of IL- 8 in response to stimulation by TNF- $\alpha$. However, even in the absence of TNF- $\alpha$, a higher level of IL-8 secretion was observed in the AA cell lines SB501 and SB521. This would suggest the presence of a basal inflammatory state up to 2.6-fold higher compared with HT-29. Taking into consideration the significant differential secretion of IL- 8 in response to TNF- $\alpha$ between the AA cell lines and HT-29, future experiments are being planned to investigate the response to anti-inflammatory cytokines, such as IL-10, 


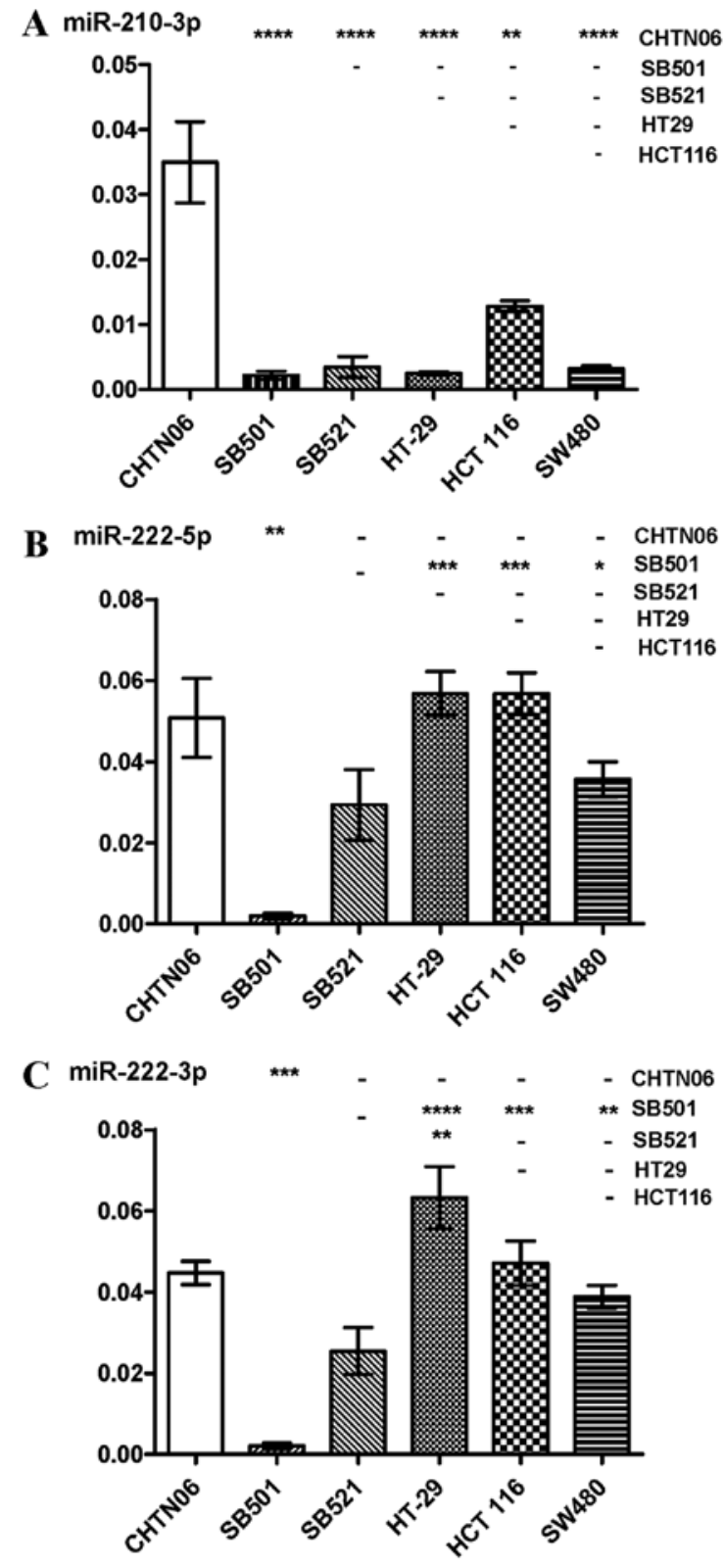

Figure 7. RT-qPCR analysis demonstrated that the expression levels of several miRNAs were dysregulated in African American colorectal carcinoma (CRC) cells compared with other well-characterized human Caucasian American CRC cell lines. (A) miR-210-3p; (B) miR-222-5p; and (C) miR-222-3p. -, not significant $(\mathrm{P}>0.05) ;{ }^{*} \mathrm{P} \leq 0.05 ;{ }^{* * *} \mathrm{P} \leq 0.01 ;{ }^{* * *} \mathrm{P} \leq 0.001 ;{ }^{* * * *} \mathrm{P} \leq 0.0001$. RT-qPCR, reverse transcription-quantitative polymerase chain reaction.

and anti-inflammatory drugs associated with CRC prevention, such as aspirin and other NSAIDs $(12,13)$.

\section{Discussion}

The availability of the appropriate cell culture and animal models is crucial for studying the development and chemoresponsiveness of colonic diseases in vitro and in vivo. Particularly important for addressing issues of racial disparity in CRC is the access to cell lines of diverse populations. These cell lines allow for the characterization of cellular and molecular properties responsible for the differential CRC incidence observed in AAs compared with CAs. Cell culture and animal models exist for cell lines derived from the tissue

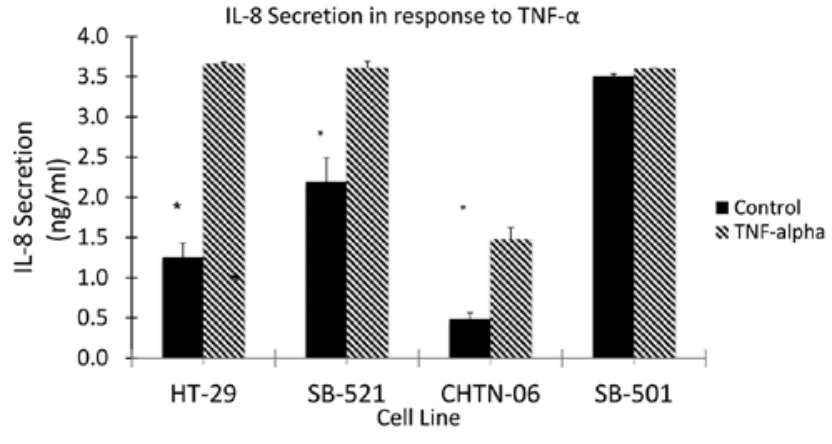

Figure 8. Inflammatory patterns expressed by African American (AA) colorectal carcinoma cell lines. The secretion levels of the pro-inflammatory cytokine IL- 8 in response to the induction of inflammation by $30 \mathrm{ng} / \mathrm{ml}$ of tumor necrosis factor (TNF)- $\alpha$ for $6 \mathrm{~h}$. The AA cell lines SB521, CHTN06 and SB501 were compared with the Caucasian American-derived cell line HT-29. ${ }^{*} \mathrm{P}<0.05, \mathrm{n}=3$.

of CA CRC patients. However, such tools for studying CRC with an AA background did not exist to date. In the present study, the unique CRC cell lines CHTN06, SB501 and SB521 were established and characterized. Each respective cell line was derived from a single human patient sample and exhibited histological characteristics consistent with well-differentiated colonic epithelial cell lineage. The epithelial nature of each cell line was further confirmed by photomicroscopy, electron microscopy and H\&E staining. Additionally, it was demonstrated that the three cell lines proliferate under cell culture conditions, undergo subculturing without immortalization, and are readily established as engrafted tumors in mouse xenograft models. STR DNA profiling at multiple culturing passages matched the original patient tissue for CHTN06 and SB501; while SB521 did not match the original patient specimen with confidence, further analysis concluded that this cell line is MSI-H, thus explaining the high degree of genomic instability. This characteristic will be used as a model for studying MSI-H in CRC patients of African background. Additionally, extensive search of the STR DNA profile for each of the three AA cell lines revealed that they are unique among all cell repositories. These cell lines represent a novel and valuable tool for investigating the molecular differences involved in the disparity in the incidence of CRC and response to chemotherapeutic and anti-inflammatory agents observed in AAs in respect to CAs.

Several transcription factors are known to be dysregulated in CRC tissue. p53 regulates the cell cycle by arresting growth in the G1/S transition and initiating apoptosis (30). p53 expression in CHTN06 and SB521 was found to be downregulated compared with HT-29. p53 nuclear accumulation, which is characteristic of aberrant mutant p53 expression, was observed in all three AA CRC cell lines. Sequestration of p53 in the nucleus is well-characterized in cases of CRC with mutant TP53 (31,32). Indeed, the CHTN06 cell line was found, as determined by sequencing of the region of interest (Agilent Technologies, Inc., Santa Clara, CA, USA), to have a single nuclear polymorphism at residue 72, namely Pro/Pro as opposed to the favorable wild-type Arg/Arg (data not shown). We also reported the increased expression of villin-1 in CHTN06, SB521 and SB501 cells compared with the HT-29 cell line. Villin-1, a member of the calcium-regulated actin-binding 
Table I. P-values obtained from RT-qPCR analysis of selected miRNAs.

\begin{tabular}{|c|c|c|c|c|c|}
\hline & vs. SW480 & vs. HCT 116 & vs. HT-29 & vs. SB521 & vs. SB501 \\
\hline \multicolumn{6}{|l|}{ miR-17-5p } \\
\hline CHTN06 & 0.0022 & 0.0008 & 0.0028 & 0.0004 & \\
\hline SB501 & a & a & a & a & \\
\hline SB521 & 0.0007 & 0.4196 & 0.0557 & & \\
\hline HT-29 & 0.2603 & 0.1397 & & & \\
\hline HCT 116 & 0.0081 & & & & \\
\hline \multicolumn{6}{|l|}{ miR-17-3p } \\
\hline CHTN06 & 0.91605 & 0.05901 & 0.04345 & 0.00710 & 0.01547 \\
\hline SB501 & 0.00014 & 0.00549 & 0.05330 & 0.00709 & \\
\hline SB521 & 0.00003 & 0.00504 & 0.20869 & & \\
\hline HT-29 & 0.00194 & 0.06891 & & & \\
\hline HCT 116 & 0.00342 & & & & \\
\hline \multicolumn{6}{|l|}{ miR-21-5p } \\
\hline CHTN06 & 0.00236 & 0.05938 & 0.00525 & 0.00080 & 0.00346 \\
\hline SB501 & 0.00019 & 0.01316 & 0.08382 & 0.00019 & \\
\hline SB521 & 0.00001 & 0.00346 & 0.25203 & & \\
\hline HT-29 & 0.00027 & 0.01608 & & & \\
\hline НCТ 116 & 0.81609 & & & & \\
\hline \multicolumn{6}{|l|}{$\operatorname{miR}-21-3 p$} \\
\hline CHTNO6 & 0.00067 & 0.03299 & 0.00124 & 0.00152 & 0.00001 \\
\hline SB501 & 0.00006 & 0.00068 & 0.00001 & 0.07711 & \\
\hline SB521 & 0.00320 & 0.01392 & 0.07896 & & \\
\hline HT-29 & 0.00233 & 0.01612 & & & \\
\hline НCТ 116 & 0.03513 & & & & \\
\hline \multicolumn{6}{|l|}{ miR-128-3p } \\
\hline CHTN06 & 0.0027 & 0.1969 & 0.0196 & 0.0139 & 0.0054 \\
\hline SB501 & 0.0227 & 0.0055 & 0.0015 & 0.1626 & \\
\hline SB521 & 0.0190 & 0.0266 & 0.1569 & & \\
\hline HT-29 & 0.0004 & 0.0425 & & & \\
\hline HCT 116 & 0.0021 & & & & \\
\hline \multicolumn{6}{|l|}{ miR-182-5p } \\
\hline CHTN06 & 0.015 & 0.207 & 0.004 & 0.002 & a \\
\hline SB501 & $\mathrm{a}$ & $\mathrm{a}$ & $\mathrm{a}$ & $\mathrm{a}$ & \\
\hline SB521 & 0.181 & 0.010 & 0.762 & & \\
\hline HT-29 & 0.189 & 0.022 & & & \\
\hline НCТ 116 & 0.108 & & & & \\
\hline \multicolumn{6}{|l|}{$\operatorname{miR}-210-3 p$} \\
\hline CHTN06 & 0.0003 & 0.0021 & 0.0002 & 0.0018 & 0.0004 \\
\hline SB501 & 0.2917 & 0.0005 & 0.7040 & 0.5037 & \\
\hline SB521 & 0.8769 & 0.0065 & 0.5783 & & \\
\hline НТ-29 & 0.2745 & 0.0003 & & & \\
\hline НCT 116 & 0.0005 & & & & \\
\hline \multicolumn{6}{|l|}{$\operatorname{miR}-222-5 p$} \\
\hline CHTN06 & 0.4669 & 0.1613 & 0.1715 & 0.0796 & 0.0037 \\
\hline SB501 & 0.0015 & 0.0005 & 0.0005 & 0.0003 & \\
\hline SB521 & 0.0753 & 0.0122 & 0.0140 & & \\
\hline HT-29 & 0.0379 & 0.9962 & & & \\
\hline HCT 116 & 0.0347 & & & & \\
\hline \multicolumn{6}{|l|}{$\operatorname{miR}-222-3 p$} \\
\hline CHTN06 & 0.2202 & 0.7168 & 0.0865 & 0.0404 & 0.0001 \\
\hline SB501 & 0.0002 & 0.0012 & 0.0014 & 0.0156 & \\
\hline SB521 & 0.1047 & 0.0530 & 0.0170 & & \\
\hline HT-29 & 0.0407 & 0.1626 & & & \\
\hline НCТ 116 & 0.2523 & & & & \\
\hline
\end{tabular}

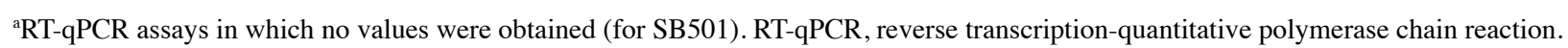


family, functions in the bundling, capping and severing of actin filaments, and its expression has been associated with tumors that are better differentiated $(23,24)$, a feature observed in the CRC cells of AA background. There was no notable expression of villin-1 in HCT116 and SW680 cells. To date, no definitive molecular markers have been identified that would allow for early detection, optimal therapeutic treatment and/or possible chemoprevention of CRC. This is particularly true for AA patients with CRC. Barriers to this have been the unavailability or limited availability of CRC cell lines or tissues from AA patients with CRC.

Dysregulation of miRNAs are well-documented across several types of cancer, and may serve as potential biomarkers for cancer classification and prognosis (33). miRNAs may act as either tumor suppressors by inhibiting oncogenic gene expression or, conversely, as oncomirs by inhibiting tumor suppressor gene expression. Our laboratory has previously reported dysregulated levels of several miRNAs in CRC tissue samples from AA patients as compared to CA CRC samples (34). In the present study, miR-17, miR-21, miR-128-3p, miR-182-5p, miR-210-3p and miR-222 were found to be differentially expressed in the three novel AA CRC cell lines as compared to some or all of the CA CRC cell lines. Cellular proliferation, carcinogenesis and metastasis of CRC are strongly correlated with aberrant expression of three of these miRNAs. For example, miR-182 suppresses the expression of FBXW7, a subunit of the phosphorylation-dependent ubiquitin protein ligase complex SCF, which acts as a tumor suppressor (35). This miRNA is also known to ablate expression of SATB2, a DNA-binding protein at nuclear matrix or scaffolding attachment regions, which in turn induces both metastasis and epithelial-to-mesenchymal transition in CRC (36). miR-210 has been shown in vitro to be inducible by hypoxia-inducible factor-1 in a hypoxic environment. This miRNA specifically targets VMP1, a stress-induced protein that promotes the formation of intracellular vacuoles leading to cell death (37). Therefore, increased diagnostic and prognostic efficacy for racial and ethnic diverse patients may be addressed by further exploration into dysregulations in the expression of miRNAs.

Inflammation has been documented as a risk factor for the initiation and progression of CRC (29). As such, the expression profile of the inflammatory proteins was examined in the CHTN06, SB501, SB521 and HT-29 cell lines in terms of cell signaling (cytokines). It was demonstrated that the AA cell lines display differential responses to pro-inflammatory cytokines (TNF- $\alpha$ ) involved in cell proliferation and CRC progression $(38,39)$, as the levels of IL- 8 secretion in the AA cell lines differed from those in the CA cell line HT-29. Possible explanations for our results may include i) the MSI-H status of SB-521; ii) the aberrant expression of MMR protein by all three cell lines; and iii) the reported correlation of these genetic characteristics with inflammation in CRC (40). Since this cytokine has been suggested as a biomarker for predicting response to 5-fluoruracil and cancer progression in CRC patients (41), the role of IL-8 secretion and inflammation in the AA cell lines post-treatment with 5-FU is being investigated; this may enable us to elucidate the role of the differential expression of inflammatory proteins in CRC racial disparities.

In conclusion, we herein report the establishment of three novel stable cell lines (CHTN06, SB501 and SB521) derived from AA CRC tissue samples. These cell lines are able to propagate in long-term culture, are tumorigenic in immunocompromised mice and have been cryopreserved for future experimentation. We demonstrated that these three cell lines share the characteristics of well-documented CA CRC cell lines, while at the same time they exhibit differences in the expression of several miRNAs, tumor-promoting proteins and inflammatory responses. The AA CRC cell lines described herein were generated to serve as models appropriate for generation and assessment of biomarkers for the early detection of colon cancer and prediction of therapeutic response. These cell lines alone are not anticipated to address racial health disparity, but rather to serve as a starting point. The authors are continuously working to generate additional cell lines and, with a statistically valid sample size, we hope to be able to discern differences between AA and CA, as well as among individual AA colon cancer patients. Differential expression of miRNA and different DNA methylation profiles were found between AA and CA colon cancer patients $(34,42)$. As no two individuals are alike, regardless of race or ethnicity, intra-racial and intra-ethnic differences are expected. Overall, the goal of the present study was to generate progress in the field of personalized medicine, which benefits all racial and ethnic groups. Thus, the cell lines described herein will address the need for inclusion.

\section{Acknowledgements}

The authors would like to thank the Cooperative Human Tissue Network for providing the patient CRC tissues used in this study. The Cooperative Human Tissue Network is supported by the National Cancer Institute. We would also like to thank the Biobank of Stony Brook Medicine for providing the tissue samples used to generate 'SB' cell lines. Other investigators may have received specimens from the same subjects. Technical support for histological studies was provided by the Stony Brook Medicine Research Histology Core Lab. The authors wish to thank Ms. Carol Ann Amella and Ms. Michele McTernan for editorial assistance and Maria Munoz-Sagastibelza, MS, for technical support. We would also like to thank Dr Ellen Li, whose parent grant (P20CA192994) was used to obtain the graduate student's diversity supplemental grant.

\section{Funding}

This study was supported in part by grants R01CA140487 and P20CA192994-03 Diversity Supplement.

\section{Availability of data and materials}

The data generated and analyzed in the present study are available from the corresponding author on reasonable request.

\section{Authors' contributions}

JP: Study design; data acquisition, analysis and interpretation; drafting and proofreading of manuscript. PJ: Data acquisition, analysis and interpretation; drafting of manuscript. JFL: Data acquisition, analysis and interpretation; drafting of manuscript. 
KRS: Analysis of data; supervisory role. LMR: Analysis and interpretation of data; proofreading of manuscript; supervisory role (JP). JLW: Study conception and design; analysis and interpretation of data; funding acquisition; project administration and supervision; drafting and proofreading of manuscript. All the authors have read and approved the final version of the manuscript.

\section{Ethics approval and consent to participate}

This study was approved by the Stony Brook University Institutional Review Board (approval no. 93677). Patient CRC samples and metadata obtained from CHTN and SBUMC were completely de-identified, assigned independent patient codes prior to release to the researchers, and qualified for a waiver of consent per 45CFR46.116.d. All animals were treated strictly in accordance with the National Institutes of Health guidelines for the care and use of laboratory animals, and the protocols used were approved by the IACUC at the State University of New York at Stony Brook (Animal Welfare Assurance no. A3011-01).

\section{Patient consent for publication}

Not applicable.

\section{Competing interests}

The authors declare that they have no competing interests to disclose.

\section{References}

1. Lieberman DA, Holub JL, Moravec MD, Eisen GM, Peters D and Morris CD: Prevalence of colon polyps detected by colonoscopy screening in asymptomatic black and white patients. JAMA 300: $1417-1422,2008$

2. Alexander D, Jhala N, Chatla C, Steinhauer J, Funkhouser E, Coffey CS, Grizzle WE and Manne U: High-grade tumor differentiation is an indicator of poor prognosis in African Americans with colonic adenocarcinomas. Cancer 103: 2163-2170, 2005.

3. Chien C, Morimoto LM, Tom J and Li CI: Differences in colorectal carcinoma stage and survival by race and ethnicity. Cancer 104: 629-639, 2005.

4. Clegg LX, Li FP, Hankey BF, Chu K and Edwards BK: Cancer survival among US whites and minorities: A SEER (Surveillance Epidemiology, and End Results) Program population-based study. Arch Intern Med 162: 1985-1993, 2002.

5. Cooper GS, Yuan Z and Rimm AA: Racial disparity in the incidence and case-fatality of colorectal cancer: Analysis of 329 United States counties. Cancer Epidemiol Biomarkers Prev 6: 283-285, 1997.

6. Hodgson DC, Fuchs CS and Ayanian JZ: Impact of patient and provider characteristics on the treatment and outcomes of colorectal cancer. J Natl Cancer Inst 93: 501-515, 2001.

7. Hodgson DC, Zhang W, Zaslavsky AM, Fuchs CS, Wright WE and Ayanian JZ: Relation of hospital volume to colostomy rates and survival for patients with rectal cancer. J Natl Cancer Inst 95: 708-716, 2003.

8. Mayberry RM, Coates RJ, Hill HA, Click LA, Chen VW, Austin DF, Redmond CK, Fenoglio-Preiser CM, Hunter CP, Haynes MA, et al: Determinants of black/white differences in colon cancer survival. J Natl Cancer Inst 87: 1686-1693, 1995.

9. Ries LAG, Kosary CL, Hankey BF, Miller BA, Harras A and Edwards BK (eds): SEER Cancer Statistics Review, 1973-1994, 1997.

10. Weber TK, Chin HM, Rodriguez-Bigas M, Keitz B, Gilligan R, O'Malley L, Urf E, Diba N, Pazik J and Petrelli NJ: Novel hMLH1 and hMSH2 germline mutations in African Americans with colorectal cancer. JAMA 281: 2316-2320, 1999.
11. Carethers JM: Racial and ethnic factors in the genetic pathogenesis of colorectal cancer. J Assoc Acad Minor Phys 10: 59-67, 1999.

12. Burn J, Gerdes AM, Macrae F, Mecklin JP, Moeslein G, Olschwang S, Eccles D, Evans DG, Maher ER, Bertario L, et al; CAPP2 Investigators: Long-term effect of aspirin on cancer risk in carriers of hereditary colorectal cancer: An analysis from the CAPP2 randomised controlled trial. Lancet 378: 2081-2087, 2011.

13. Tougeron D, Sha D, Manthravadi S and Sinicrope FA: Aspirin and colorectal cancer: Back to the future. Clin Cancer Res 20: 1087-1094, 2014.

14. Waugh DJ and Wilson C: The interleukin-8 pathway in cancer. Clin Cancer Res 14: 6735-6741, 2008.

15. De Simone V, Franzè E, Ronchetti G, Colantoni A, Fantini MC, Di Fusco D, Sica GS, Sileri P, MacDonald TT, Pallone F, et al: Th17-type cytokines, IL- 6 and TNF- $\alpha$ synergistically activate STAT3 and NF-kB to promote colorectal cancer cell growth. Oncogene 34: 3493-3503, 2015.

16. Goodman JE, Bowman ED, Chanock SJ, Alberg AJ and Harris CC: Arachidonate lipoxygenase (ALOX) and cyclooxygenase $(\mathrm{COX})$ polymorphisms and colon cancer risk. Carcinogenesis 25: 2467-2472, 2004.

17. Sansbury LB, Millikan RC, Schroeder JC, Moorman PG, North KE and Sandler RS: Use of nonsteroidal antiinflammatory drugs and risk of colon cancer in a population-based, case-control study of African Americans and Whites. Am J Epidemiol 162: 548-558, 2005.

18. Mackenzie GG, Sun Y, Huang L, Xie G, Ouyang N, Gupta RC, Johnson F, Komninou D, Kopelovich L and Rigas B: Phosphosulindac (OXT-328), a novel sulindac derivative, is safe and effective in colon cancer prevention in mice. Gastroenterology 139: 1320-1332, 2010.

19. Ouyang N, Williams JL and Rigas B: NO-donating aspirin isomers downregulate peroxisome proliferator-activated receptor (PPAR)delta expression in APC(min/+) mice proportionally to their tumor inhibitory effect: Implications for the role of PPARdelta in carcinogenesis. Carcinogenesis 27: 232-239, 2006.

20. Ouyang N, Ji P and Williams JL: A novel NSAID derivative, phospho-ibuprofen, prevents AOM-induced colon cancer in rats. Int J Oncol 42: 643-650, 2013.

21. Williams JL, Ji P, Ouyang N, Kopelovich L and Rigas B: Protein nitration and nitrosylation by NO-donating aspirin in colon cancer cells: Relevance to its mechanism of action. Exp Cell Res 317: 1359-1367, 2011.

22. Puvvada SD, Funkhouser WK, Greene K, Deal A, Chu H, Baldwin AS, Tepper JE and O'Neil BH: NF- $\kappa$ B and Bcl-3 activation are prognostic in metastatic colorectal cancer. Oncology 78: 181-188, 2010.

23. Al-Maghrabi J, Gomaa W, Buhmeida A, Al-Qahtani M and Al-Ahwal M: Loss of villin immunoexpression in colorectal carcinoma is associated with poor differentiation and survival. ISRN Gastroenterol 2013: 679724, 2013.

24. Arango D, Al-Obaidi S, Williams DS, Dopeso H, Mazzolini R, Corner G, Byun DS, Carr AA, Murone C, Tögel L, et al: Villin expression is frequently lost in poorly differentiated colon cancer. Am J Pathol 180: 1509-1521, 2012.

25. Brat DJ, Bellail AC and Van Meir EG: The role of interleukin-8 and its receptors in gliomagenesis and tumoral angiogenesis. Neuro Oncol 7: 122-133, 2005.

26. Alfaro C, Suárez N, Martínez-Forero I, Palazón A, Rouzaut A, Solano S, Feijoo E, Gúrpide A,Bolaños E, Erro L, et al: Carcinomaderived interleukin- 8 disorients dendritic cell migration without impairing T-cell stimulation. PLoS One 6: e17922, 2011.

27. Frouws MA, Reimers MS, Swets M, Bastiaannet E, Prinse B, van Eijk R, Lemmens VE, van Herk-Sukel MP, van Wezel T, Kuppen PJ, et al: The influence of BRAF and KRAS mutation status on the association between aspirin use and survival after colon cancer diagnosis. PLoS One 12: e0170775, 2017.

28. Zhao S, Wu D, Wu P, Wang Z and Huang J: Serum IL-10 Predicts worse outcome in cancer patients: A meta-analysis. PLoS One 10: e0139598, 2015.

29. Peddareddigari VG, Wang D and Dubois RN: The tumor microenvironment in colorectal carcinogenesis. Cancer Microenviron 3: $149-166,2010$

30. Rodrigues NR, Rowan A, Smith ME, Kerr IB, Bodmer WF, Gannon JV and Lane DP: p53 mutations in colorectal cancer. Proc Natl Acad Sci USA 87: 7555-7559, 1990.

31. Bosari S, Viale G, Bossi P, Maggioni M, Coggi G, Murray JJ and Lee AK: Cytoplasmic accumulation of p53 protein: An independent prognostic indicator in colorectal adenocarcinomas. J Natl Cancer Inst 86: 681-687, 1994. 
32. Bosari S, Viale G, Roncalli M, Graziani D, Borsani G, Lee AK and Coggi G: p53 gene mutations, p53 protein accumulation and compartmentalization in colorectal adenocarcinoma. Am J Pathol 147: 790-798, 1995.

33. Iorio MV and Croce CM: Causes and consequences of microRNA dysregulation. Cancer J 18: 215-222, 2012.

34. Li E, Ji P, Ouyang N, Zhang Y, Wang XY, Rubin DC, Davidson NO, Bergamaschi R, Shroyer KR, Burke S, et al: Differential expression of miRNAs in colon cancer between African and Caucasian Americans: Implications for cancer racial health disparities. Int J Oncol 45: 587-594, 2014.

35. Li L, Sarver AL, Khatri R, Hajeri PB, Kamenev I, French AJ, Thibodeau SN, Steer CJ and Subramanian S: Sequential expression of miR-182 and miR-503 cooperatively targets FBXW7, contributing to the malignant transformation of colon adenoma to adenocarcinoma. J Pathol 234: 488-501, 2014.

36. Yang MH, Yu J, Jiang DM, Li WL, Wang S and Ding YQ: microRNA-182 targets special AT-rich sequence-binding protein 2 to promote colorectal cancer proliferation and metastasis. J Transl Med 12: 109, 2014.

37. Qu A, Du L, Yang Y, Liu H, Li J, Wang L, Liu Y, Dong Z, Zhang X, Jiang X, et al: Hypoxia-inducible MiR-210 is an independent prognostic factor and contributes to metastasis in colorectal cancer. PLoS One 9: e90952, 2014.
38. Viatour P, Merville MP, Bours V and Chariot A: Phosphorylation of NF-kappaB and IkappaB proteins: Implications in cancer and inflammation. Trends Biochem Sci 30: 43-52, 2005

39. Brew R, Erikson JS, West DC, Kinsella AR, Slavin J and Christmas SE: Interleukin-8 as an autocrine growth factor for human colon carcinoma cells in vitro. Cytokine 12: 78-85, 2000.

40. Carethers JM, Koi M and Tseng-Rogenski SS: EMAST is a form of microsatellite instability that is initiated by inflammation and modulates colorectal cancer progression. Genes (Basel) 6: 185-205, 2015.

41. Jin WJ, Xu JM, Xu WL, Gu DH and Li PW: Diagnostic value of interleukin-8 in colorectal cancer: A case-control study and meta-analysis. World J Gastroenterol 20: 16334-16342, 2014.

42. Wang X, Ji P, Zhang Y,LaComb JF, Tian X, Li E and Williams JL: Aberrant DNA Methylation: Implications in Racial Health Disparity. PLoS One 11: e0153125, 2016.

This work is licensed under a Creative Commons Attribution-NonCommercial-NoDerivatives 4.0 International (CC BY-NC-ND 4.0) License. 